\title{
MANAGEMENT OF SECURITY ACTIVITIES AT INNOVATIVE-ACTIVE ENTERPRISES
}

\author{
Marta KOPYTKO (1) $1^{*}$, Mariya FLEYCHUK ${ }^{\circledR 2}{ }^{2}$, Mariana VERESKLIA @3 ${ }^{3}$, \\ Nataliia PETRYSHYN (i) ${ }^{4}$, Andriy KALYNOVSKYY (D) \\ ${ }^{1}$ Department of Finance and Accounting, Lviv State University of Internal Affairs, Lviv, Ukraine \\ ${ }^{2}$ High School of Enterprise and Administration in Lublin, Lublin, Poland \\ ${ }^{3}$ Management Department, Lviv State University of Internal Affairs, Lviv, Ukraine \\ ${ }^{4}$ Department of Foreign Trade and Customs, Lviv Polytechnic National University, Lviv, Ukraine \\ ${ }^{5}$ Department of Foreign Trade and Customs, Institute of Economics and Management, \\ Lviv Polytechnic National University, Lviv, Ukraine
}

Received 25 August 2020; accepted 20 June 2021

\begin{abstract}
The article identifies the fundamental problems of innovation as a factor in strengthening the economic security of an enterprise in the context of globalization and integration of the world's economic space. The factors that have a direct impact on innovation activity both in the country and in the world have been investigated. Clustering of individual countries was carried out and Ukraine's place among them was determined according to the Global Innovation Index. Using the software packages MS Excel and CurveExpert 5.0, a study of the index of innovative efficiency in Ukraine was carried out; dynamics of financing innovative activities in Ukraine, as well as the impact of the level of capital investment on the volume of financing innovative activities. It is proposed to assess the level of economic security of an enterprise based on indicators of its innovative development. The features of interpreting the concept of "innovative activity of enterprises" have been investigated. The sequence and interconnection of such categories as innovative potential, innovative activity, and innovative activity are analyzed. The structure of the process of innovation activity has been investigated. The rhombus of innovative activity is analyzed, which is formed from the following elements: receptivity to new things - provision of resources - communication and organization of the innovation process - a measure of competence. In the study of the specifics of the management of innovative-active enterprises, the analysis of the features and comparison of the differences between innovation activity and other types of economic activity was carried out. The structure of the process of managing innovatively active enterprises has been developed, taking into account aspects of the safety of activities. The prospect of further research identified a thorough analysis of the features of the management process of innovatively active enterprises, considering the impact of global risks and threats. The principal purpose of the article is to study the essence and main characteristics of innovatively active enterprises in the study's context of the security aspect.
\end{abstract}

Keywords: innovation activity of enterprises, innovation activity, innovation potential, security policy activities, hazards, management of innovative enterprises, global threats, COVID-19.

JEL Classification: 031, M1, L53, H12, H56.

\section{Introduction}

The current stage in the development of world economic relations, the challenges of the globalisation of economic processes, the desire of most countries to integrate into the international community cause reformatting the current domestic economic system and the search for new methods, forms and ways of carrying out production, technological and technical activities. Under such conditions, the problem of increasing the innovation factor, which is an integral component of scientific and technological progress, in the system of economic relations and economic security of an enterprise, based on competitiveness and activation of innovative development, is actualized (Lazonick, 2011).

Today, the impact of the global economic system on the sustainable socio-economic development of the country

*Corresponding author. E-mail: marta_kernytska@ukr.net 
entrepreneurship in particular, and sectors of the national economy is tangible. At the present stage, there is such a tendency that individual innovative developments such as "cloud" computing, 3D printer, big data have been integrated into independent new separate industries. At the same time, traditional industries, such as healthcare and insurance, and logistics, require an innovative approach. Using artificial intelligence would be expedient in this context. Of course, the increasing needs and requirements of a person and a citizen in society determine the need to improve production, technological competition, introducing new technologies, and, the progressive development of science and technology and the relevance of the development and implementation of innovative development strategies by enterprises. Since innovations are characterized by a continuous and purposeful process of searching for innovations, which is understood as a specific activity for the development, creation and implementation of a set of interactions to get a positive socio-economic and scientific-technical process, their main feature is interactivity, which actualizes problem research (Seifert et al., 2007).

Of course, innovative development is a priority area of the enterprise. In a market economy, an enterprise experiences the influence of the external global environment, which provokes instability, constant dynamics and reduces the level of economic security, which manifests itself in ensuring the progressive economic development of society in order to carry out production activities to meet individual and social needs, and is also characterized by the degree of protection of all systems enterprises in the implementation of economic activities and prevention of information leakage (Duhan \& Singh, 2014). Innovations, are one of the main factors for ensuring the effective functioning and economical use of resources at the enterprise, the quality of business processes and a constant incentive for capacity building and sustainable development of the enterprise.

In the process of enterprise's activities in modern conditions are faced with a large number of risks and threats, which are manifested in negative macroeconomic impacts of restrictions, manifestations of unfair competition, problems in the field of staffing, lack of funds, leakage of confidential information, and the like. All these aspects make certain adjustments to the management process, which should set risk management as the principal goal, presupposes a focus on ensuring economic security. That is, a situation arises in which the management process is impossible without the functioning of an effective system of economic security (Shpak et al., 2014).

Even more specific is the process of managing innovatively active enterprises, because they are characterized by a significantly higher riskiness of activities and the level of failure or getting a stunning effect is also higher compared to other enterprises. In this regard, the issues of organizing this process, taking into account the specifics of innovation, require a priority solution.

\section{Literature review}

The main issues of innovation were studied by many scientists, who considered innovation to be a driving force of economic growth and social progress and at the same time a risk factor for stable traditionally operating systems (Abebe et al., 2000)

Ranft and Lord (2002) associate innovation with continuous and purposeful processes of finding, preparing and implementing production improvement.

At the same time Dachs et al. (2008) substantiated the need for research in the field of innovation and in the context of ensuring the economic security of the enterprise is associated with the formation of the paradigm of the new economy (from the economy of the information sphere to the digital economy) as a special area of theoretical and applied research, since in recent years, the scientific environment is actively undergoing processes conceptualization of the phenomenon of neoeconomics and its structural elements.

In turn, Lewandowska et al. (2016), in his work, examined the experience of Poland in the development of innovatively active enterprises, and also highlighted the main security problems that an enterprise may face on the way to developing its innovative activity.

Nursoy et al. (2012) are focused on implementing the method of information-time support of global, local socio-political and other processes in the modern security environment both at the micro- and macro-level, the essence of which is the use of several analytical, logical, expert, comparative and other procedures to which information is exposed during an assessment without a pitch environment for threats, risks and destructive phenomena at a specific time interval.

In the functioning of any enterprise, innovative activity has the prerequisites for its occurrence, that is, the enterprise must have the appropriate conditions, resources and the desire of employees (with the support of management) for its implementation. That is, there must be an innovative potential (Gurieva et al., 2016). Innovative potential, according to Iastremska and Stokovych (2019) these are opportunities both for the explicit realization of the enterprise's capabilities to introduce innovations, and in hidden opportunities that are currently not used; these characteristics can have both an actual result and a planned or desired one or another macroeconomic and internal conditions of an enterprise.

If we turn to recent studies of innovative activity in enterprises, then it is worth paying attention to the study of Wyrwa (2020), who investigated the transformation of innovatively active enterprises in the context of Industry 4.0 and gave a forecast for the development of innovatively active enterprises until 2027. This study is especially interesting for our work in the presence's context of mathematically formed forecasts regarding the future activities of innovative enterprises in Europe. 


\section{Data}

At the present stage, the level of innovativeness of an enterprise depends on the degree of innovative development of the country; it is possible to quantify the degree of influence of globalization of these factors. At the international level, an integral assessment of the state of development of the innovation system is carried out and international rankings are created by indicators of innovation, in particular (Sharp et al., 2017):

- Global Innovation Index;

- Bloomberg Innovation Index (Bloomberg Innovation Index);

- Global Competitiveness Index;

- Innovation Union Scoreboard;

- Global Talent Competitiveness Index;

- Readiness for the Future of Production Assessment.

Note that Ukraine's positions in these ratings are not leading, therefore, we consider it appropriate to analyze the main ones.

The Global Innovation Index is compiled by Cornell University, INSEAD Business School, and the World Intellectual Property Organization. Table 1 shows the clustering according to the Global Innovation Index of individual countries taking part in the ranking and Ukraine's place among them.

As you can see, Ukraine's position is rather low according to the Global Innovation Index, which is evidenced by the low level of innovation activity in the country and the presence of destabilizing factors of the economic security of enterprises. Note that highly developed countries are located within 1 and 2 clusters, while developing countries and countries with a low level of economic development are located in 3 and 4 clusters. At the same time, countries such as Poland and Greece belong to highly developed countries, but took a position in cluster 3 , which is associated with significant macroeconomic imbalances in these countries, caused by financial and economic instability in countries and the concentration on their territory of a significant number of workers and their illegal employment from the countries of Eastern Europe, including Ukraine. Under such conditions, there is an "outflow" of innovation potential to highly developed countries than a decrease in the indicators of the Global Innovation Index in Ukraine.

Detailed analysis of the index of innovative efficiency of Ukraine in 2010-2018 (Figure 1), which is determined by rating the ratio of the Innovative Output Index to the Innovative Input Index, suggests that the creation of an enabling environment for innovative performance has declined sharply. However, forecast estimates show that in the conditions of 2019-2020. The value of the indicator under consideration has a tendency to increase.

According to the Iastremska et al. (2019), the dynamics of total factor productivity in countries with different levels of development (Figure 2) is an indicator of the growth of innovative activity of enterprises.

Table 1. Grouping of selected countries of the world by the Global Innovation Index, 2019

\begin{tabular}{|c|c|c|c|c|c|c|c|}
\hline No. & Country & $\begin{array}{l}\text { Cluster } \\
\text { number }\end{array}$ & Rating & No. & Country & $\begin{array}{l}\text { Cluster } \\
\text { number }\end{array}$ & Rating \\
\hline 1. & Switzerland & \multirow{10}{*}{1} & 67.24 & 21. & Latvia & \multirow{10}{*}{3} & 43.23 \\
\hline 2. & Sweden & & 63.65 & 22. & Lithuania & & 41.46 \\
\hline 3. & USA & & 61.73 & 23. & Poland & & 41.31 \\
\hline 4. & Netherlands & & 61.44 & 24. & Greece & & 38.90 \\
\hline 5. & United Kingdom & & 61.30 & 25. & Russian Federation & & 37.62 \\
\hline 6. & Finland & & 59.83 & 26. & Ukraine & & 37.40 \\
\hline 7. & Denmark & & 58.44 & 27. & Georgia & & 36.98 \\
\hline 8. & Singapore & & 58.37 & 28. & Romania & & 36.76 \\
\hline 9. & Germany & & 58.19 & 29. & India & & 36.58 \\
\hline 10. & Israel & & 57.43 & 30. & Philippines & & 36.18 \\
\hline 11. & Republic of Korea & \multirow{10}{*}{2} & 56.55 & 31. & Brazil & \multirow{10}{*}{4} & 33.82 \\
\hline 12. & China & & 54.82 & 32. & Belarus & & 32.07 \\
\hline 13. & Japan & & 54.68 & 33. & Ecuador & & 26.56 \\
\hline 14. & France & & 54.25 & 34. & Nigeria & & 23.93 \\
\hline 15. & Canada & & 53.88 & 35. & Cameroon & & 23.90 \\
\hline 16. & Luxembourg & & 53.47 & 36. & Bangladesh & & 23.31 \\
\hline 17. & Norway & & 51.87 & 37. & Zimbabwe & & 22.30 \\
\hline 18. & Austria & & 50.94 & 38. & Niger & & 18.13 \\
\hline 19. & Italy & & 46.30 & 39. & Burundi & & 17.65 \\
\hline 20. & Hungary & & 44.51 & 40. & Yemen & & 14.49 \\
\hline
\end{tabular}


It is worth noting that a decline in productivity growth in the context of globalization doubts will lead to a decrease in the country's economy's ability to respond to shocks in a strategic perspective. In particular, several destabilizing factors can be identified that lead to a decrease in the innovative activity of enterprises (Figure 3).

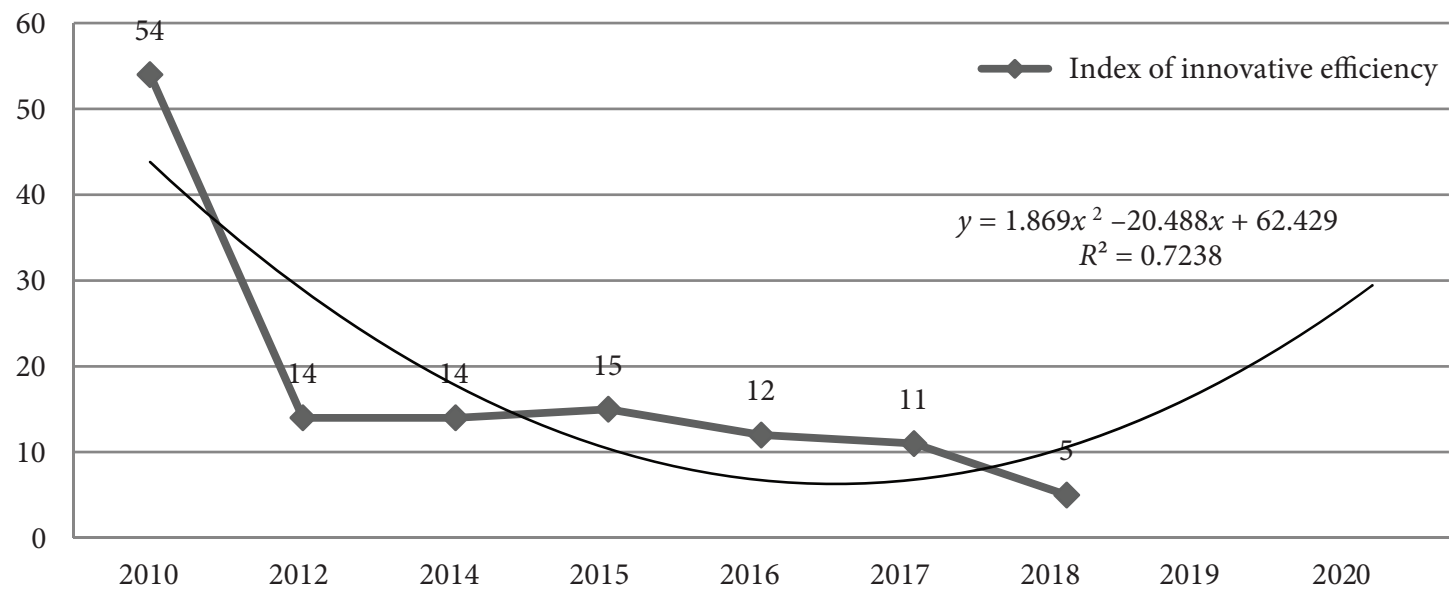

Figure 1. Forecast estimates of the innovation efficiency index in Ukraine 2010-2020 (2019-2020 - forecast estimates)

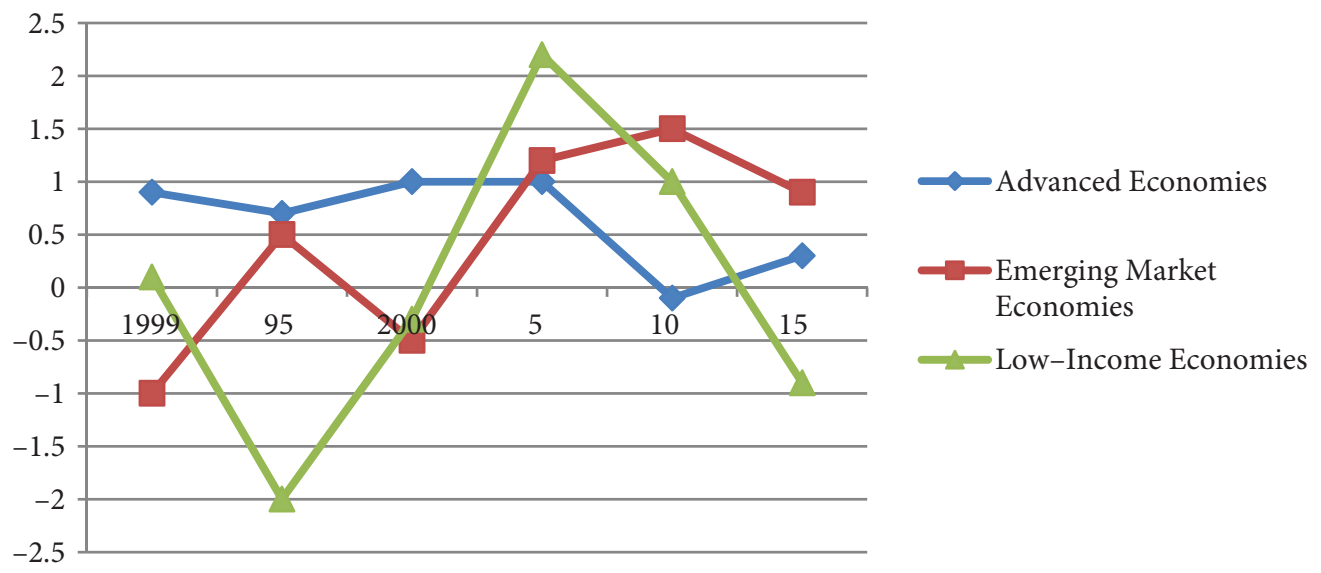

Figure 2. Dynamics of total factor productivity in countries with different levels of development, 5-year average rates, $\%$

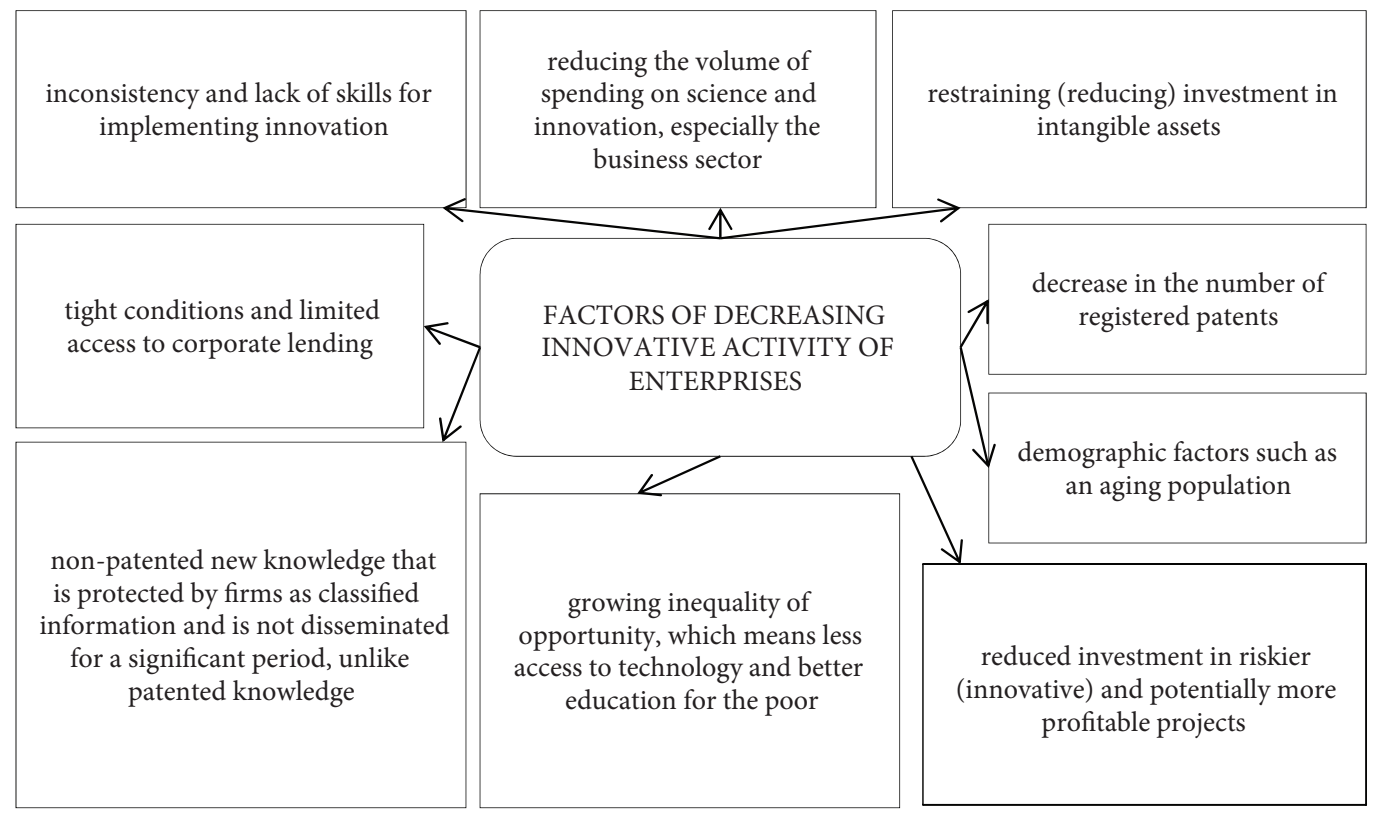

Figure 3. Factors of reducing the innovative activity of enterprises in Ukraine 
The study of the factors influencing the level of innovative activity of enterprises shows its dependence on macroeconomic stability, the level of socio-economic development of the country, and the volume of funding for innovation.

It is worth paying attention to the fact that the economic security of enterprises from the standpoint of global ratings cannot be assessed without considering the indicators of innovative development. At the same time, agreeing with Boronos and Shkarupa (2020), we believe that innovation as a factor in strengthening the economic security of an enterprise in the context of globalization and integration into the world economic space and stimulating innovation are vectors for implementing strategic priorities Ukraine, implementing of which depends on the level of budgetary and extra budgetary financing of the sphere of innovations.

Along with this, the primary and significant destabilizing factor of both the economic security of enterprises and the development of innovative activities is the low level of funding for innovations, which reflects its impact on their productivity. In Figure 4 reflects the dynamics of financing innovative activities in Ukraine for the period from 2011 until 2017.

As you can see, the dynamics of financing innovative activities in Ukraine in the period under review is characterized by a downward trend, and the share of financing innovative activities is extremely low.

Note that the main source of financing for innovative activities is the own funds of enterprises. At the same time, the results of the study using nonlinear programming tools (polynomial model, statistical package CurveExpert 5.0) make it possible to trace the directly proportional relationship between the amount of funding for innovative activities and the amount of capital investment in the innovation sphere. Note that, in turn, increasing the level of economic security of the enterprise, the main task of which is to provide strategic, tactical and operational measures for the security of the enterprise depends on the level of formation of unique capabilities for modernization.

According to the conducted economic and mathematical calculations, it can be concluded that the financing of innovative activities is a risky process; however, it is the basis for the stable and effective development of the enterprise.

\section{Research model}

One type of enterprise activity is innovation activity. Analyzing the Figure 5, it can be concluded that the identification of innovative activity with innovative activity and positioning innovative activity as the ability to innovate are erroneous, because innovative activity characterizes the real innovative potential of an enterprise and describes the degree of intensity of implementation of innovative projects (Boronos \& Shkarupa, 2020)

Olefirenko and Shevliuga (2017) proposes such a structure of the process of innovation activity under the concept of a "black box" - Figure 6 .

The use of the "black box" method allows us to determine the combination of the most important factors of the innovation process of the enterprise, which form the so-called diamond of innovation activity (Figure 7): receptivity to the new - provision of resources - communication and organization of the innovation process - a measure of competence.

Particularly noteworthy is the study of the innovative susceptibility of an enterprise, which shows the ability of personnel and management to identify and use both external and internal opportunities to activate the process of innovation. It is the formation of a high level of innovative susceptibility of an enterprise that requires significant efforts, because it is necessary to carefully monitor changes in the external environment according to information, new publications, patents, the formation of innovative collaborations, the results of innovative activities of competitors, the study of best practices in implementing

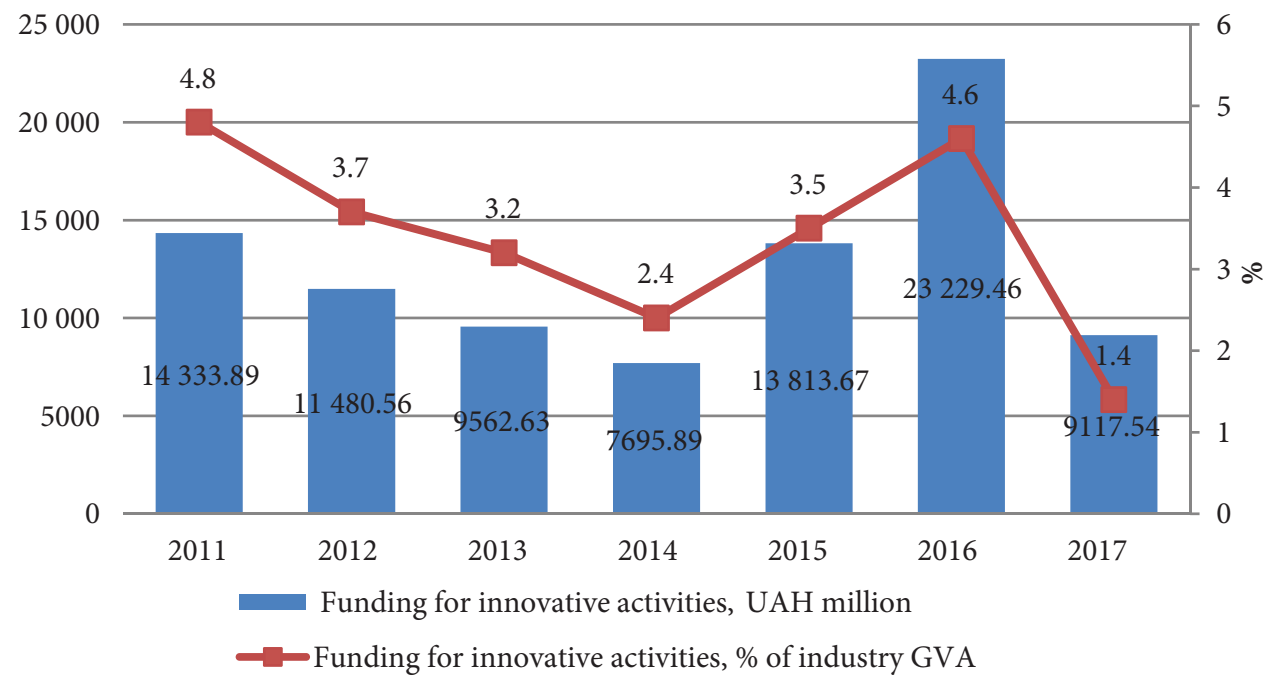

Figure 4. Dynamics of financing innovative activities in Ukraine, 2011-2017 
innovative projects, the promotion of innovative activity of personnel on enterprises-leaders in the field of innovation. The most difficult thing is to analyze the collected information, because there is a lot. Therefore, there is a need to attract highly qualified workers, because of the use of technical devices to analyze this kind of information will not give the desired result.

So, highly qualified personnel are the primary resource for ensuring the innovative activity of the enterprise. The determining factor is the indicator of employees' innovative competence. After all, only the experience and proven skills of innovators-workers can achieve significant results in innovative activities.

The organization of labor at the enterprise and the level of building the organizational structure and corporate culture are important for the success of innovative projects. The importance of these processes is determined by the need to create a comfortable environment for work and the opportunity for the manifestation of creativity in it.

Thus, having studied the essence and features of the innovative activity of enterprises, it is necessary to analyze the specifics of the management of such enterprises.

\section{Results and discussions}

During the research, we tried to solve the following questions:

- to reveal the essence and understand the features of the functioning of innovatively active enterprises in the context of the study of security on the territory of Ukraine.

- to form and research the main parameters by which it can be concluded that enterprises are innovatively active.

- to investigate the main factors of influence for innovatively active enterprises.

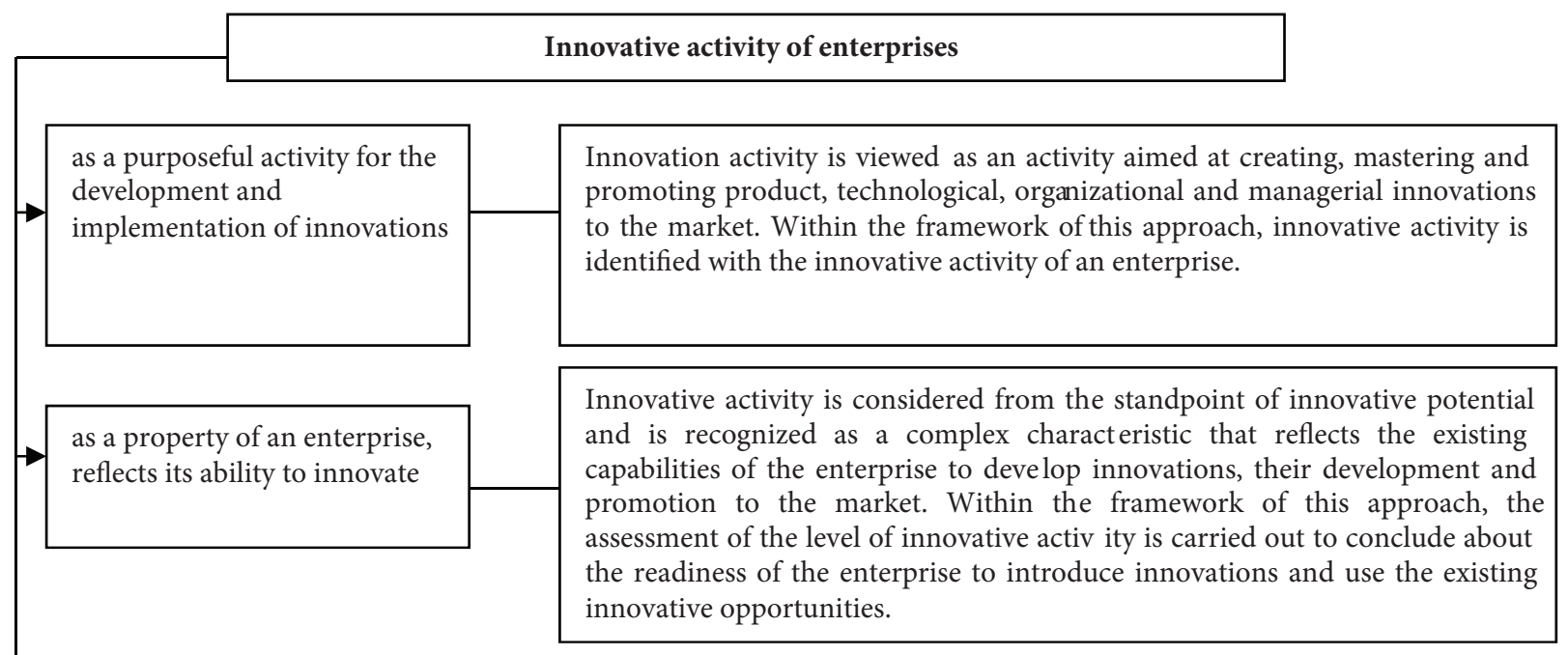

as a characteristic of the innovative activity of the enterprise
Innovative activity is defined as a feat ure that characterizes the innovative activity of an enterprise. The level of innovative activity is an indicator that allows you to assess the degree of inte nsification of innovative activity at the enterprise.

Figure 5. Analysis of scientific approaches to understanding the essence of innovative activity of enterprises

\begin{tabular}{|c|c|c|}
\hline Input & & Exit \\
\hline $\begin{array}{l}\text { 1. Innovative sensitivity of the } \\
\text { enterprise } \\
\text { 2. Resource security } \\
\text { Reflects the innovative activity of } \\
\text { the consumer }\end{array}$ & $\begin{array}{l}\text { The quality of organizational and } \\
\text { managerial decisions and the quality } \\
\text { of communication as the main } \\
\text { condition for creative activity } \\
\text { Reflects innovative activity in the } \\
\text { development of his company }\end{array}$ & $\begin{array}{l}\text { Innovative competence, that is, } \\
\text { the level and timeliness of the } \\
\text { release of innovative products } \\
\text { Reflects the level of innovation } \\
\text { activity of the supplier }\end{array}$ \\
\hline
\end{tabular}

Figure 6. The structure of the process of innovation activity of the enterprise 
The specificity of managing innovatively active enterprises is formed on the basis of the characteristics of innovative activity as an object of management and its difference from other types of economic activity. An analysis of the characteristics and comparison of the differences between innovation activity and other types of economic activity of enterprises are given in Table 2 .

As you can see from the Table 2, the level of riskiness of activity is a determining factor in the management of innovative activity of enterprises. This means that all divisions must, within the limits of their authority, determine the level of risks and their impact on activities, as well as maximally contribute to minimizing their impact. Staffing at the enterprise is of great importance in managing innovation risks. It is the personnel that has the greatest influence on the level of success of innovative projects, and predetermines the possibility of a certain risk management (Lombardi et al., 2012).

In the managerial practice of the leading innovating states (USA, Japan, Germany), there is a practice of stimulating the innovative activity of workers, in particular, for this purpose, appropriate departments are created at enterprises that handle for training and advanced training of workers for the implementation of innovative activities.

\section{INNOVATIVE SENSITIVITY:}

- receptivity to information about innovation (new books, articles, exhibitions, conferences, new educational courses) and the willingness to regularly accumul ate, study and apply the information received;

- receptivity to the best practices that are created within the organization, and the experience of competitors, the willingness to study this experience, measure their own and others' achievements and compare them (readiness for benchmarking);

- susceptibility to the most innovations, new technologies and new products, susceptibility to the innovation process and innovation and the willingness to overcome the difficulties of mastering innovations;

- the level of self-actualization of employees and the presence of needs for intellectual work, educational and career growth, solving situations, problems and tasks, participation in projects, success, results and achievements, willingness to include innovations in your business process.

\section{INNOVATIVE COMPETENCE:}

Reflects innovative activity from a supplier's perspective.

First, the factor that determines the impact on the environment is assessed - the level of competence of the innovations, technologies and related products offered by the supplier: how high are the properties of the products (what level of progress are the technologies and products supplied), how high-quality and timely they are. And then the factors reflecting the state of the internal environment are assessed: the level of competence of employees, groups, teams, departments and organizations, that is, the level of their knowledge:

1) theoretical and methodological knowledge;

2) professional knowledge of the types of activities (functions) and the ability to solve standard tasks and situations, to perform similar operations;

3) experience and skills in solving complex situations and problems;

4) ability and experience of applying a creative approach to solving complex problems and nonstandard systemic tasks (projects).

The renewal of their knowle dge is taken into account.

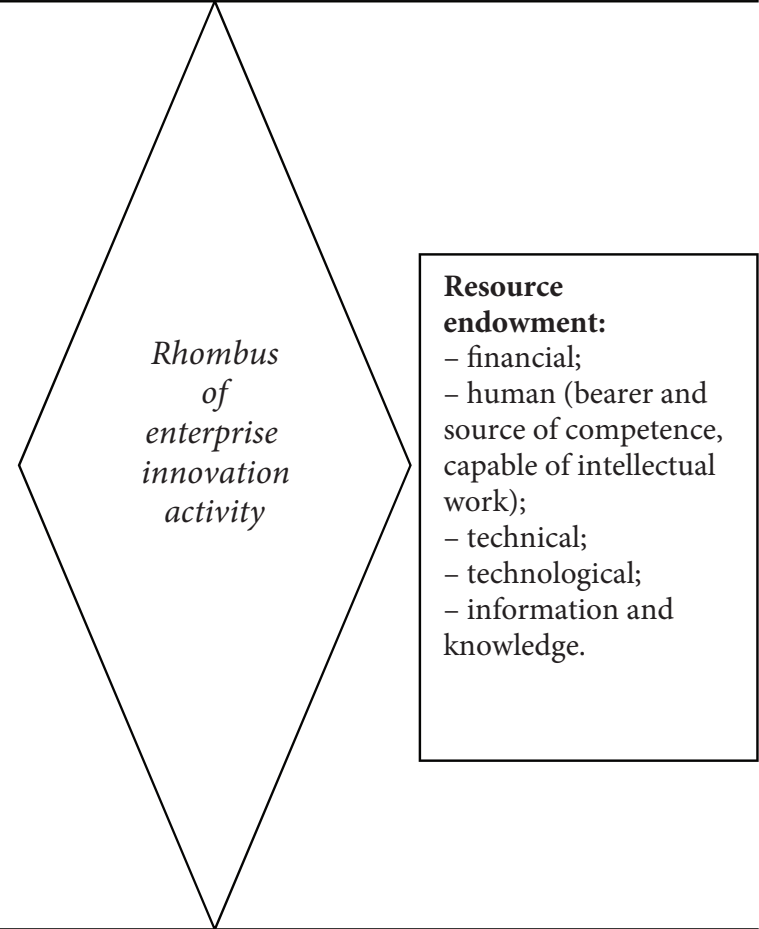

ORGANIZATION QUALITY AND COMMUNICATION:

two components: communication between the performers of the process, because the level of communication forms creativity, participants and the state of the innovation process itself, its organization and efficiency.

The level of communication between empl oyees is assessed by the state of:

- information and communication technologies;

- organizational structure;

- corporate culture.

The level of their renewability and compliance with pr oduction processes, acquisition, accumulation, training, movement, transfer (transaction) and dissemination of knowledge is taken into account. Further, the innovation process itself, its stages, the effectiven ess of intellectual work are assessed. 
Table 2. Analysis of the characteristics and comparison of differences between innovation activity and other types of economic activity

\begin{tabular}{|c|c|c|}
\hline Distinctive feature & Features of traditional activities & Features of innovation \\
\hline $\begin{array}{l}\text { The level of riskiness } \\
\text { and uncertainty of } \\
\text { activities }\end{array}$ & $\begin{array}{l}\text { Moderate level of risk and } \\
\text { uncertainty }\end{array}$ & $\begin{array}{l}\text { High level of uncertainty and high level of risks because of the } \\
\text { complexity of forecasting the results of innovation activities. }\end{array}$ \\
\hline $\begin{array}{l}\text { Priority of provision } \\
\text { of labor and financial } \\
\text { resources }\end{array}$ & $\begin{array}{l}\text { The issue of the provision of } \\
\text { labor and financial resources is } \\
\text { important, but their limitedness } \\
\text { will not lead to catastrophic } \\
\text { consequences }\end{array}$ & $\begin{array}{l}\text { For the success of innovation, financial and human resources are } \\
\text { decisive, because it requires constant investment in the technological } \\
\text { process and personnel interested in its effectiveness. }\end{array}$ \\
\hline $\begin{array}{l}\text { Priority of issues to } \\
\text { be resolved }\end{array}$ & Addressing organizational issues & $\begin{array}{l}\text { The need to resolve issues: } \\
\text { - coordination of actions of participants in the innovation process; } \\
\text { - providing resources and commercialization of innovative products; } \\
\text { - ensuring information and economic security, which allows you to } \\
\text { preserve the ownership of innovative products. }\end{array}$ \\
\hline $\begin{array}{l}\text { Variability and } \\
\text { inconstancy of } \\
\text { control objects }\end{array}$ & $\begin{array}{l}\text { The control process is aimed at } \\
\text { fairly stable objects characterized } \\
\text { by predictable dynamics of } \\
\text { parameters }\end{array}$ & $\begin{array}{l}\text { Changes in the object of management arising from the improvement of } \\
\text { objects of labor, changes in goods or services, etc. }\end{array}$ \\
\hline $\begin{array}{l}\text { Stages of the life } \\
\text { cycle of goods and } \\
\text { services covered }\end{array}$ & $\begin{array}{l}\text { The last stage of production and } \\
\text { economic activity is characterized } \\
\text { by the release of a product or } \\
\text { service }\end{array}$ & $\begin{array}{l}\text { The issue that requires a priority solution in the life cycle of an } \\
\text { innovative product is its industrial development and commercialization. }\end{array}$ \\
\hline $\begin{array}{l}\text { The existence of } \\
\text { resistance from } \\
\text { personnel and } \\
\text { consumers }\end{array}$ & There are isolated cases & $\begin{array}{l}\text { Resistance from staff and consumers is a common occurrence, which } \\
\text { leads to negative consequences that must be responded to in a timely } \\
\text { manner. }\end{array}$ \\
\hline $\begin{array}{l}\text { Role of knowledge } \\
\text { and level of creativity }\end{array}$ & $\begin{array}{l}\text { Knowledge is essential to meet } \\
\text { your goals with a minimum level } \\
\text { of creativity }\end{array}$ & $\begin{array}{l}\text { Knowledge and the level of creativity are the determining factors for } \\
\text { the success of innovation and require a specific way of management for } \\
\text { their carriers. }\end{array}$ \\
\hline
\end{tabular}

The work of such departments is to help unleash the potential of employees, which will later be used to develop the innovativeness of a particular industry. An important method of stimulating innovation activity is to promote the integration of education into the business environment. As noted by scientists Guk and Korobeynik (2010), universities and enterprises are working on solving the same problems, but universities are generally ahead, because they have the opportunity to attract leading scientists and have an appropriate basis for research.

The process of managing an innovatively active enterprise is complex and requires additional efforts from managers at different levels. So, top-level managers should form and make timely adjustments to the innovation strategy and form an appropriate policy for its achievement, lower-level managers should maximize the achievement of certain priorities and monitor the resource provision of the process, managers of low management levels should correspond to the maximum efficiency of the unit operations being carried out. Managers at all levels face a number of challenges that create obstacles to achieving corporate goals.

In the works of Ivanchenko (2010), Grizovska (2014) analyzed the main factors that determine the refusal of enterprises from innovations:

1. Significant expenditure of resources, including financial. The innovative activity of the enterprise makes changes in its daily functioning: departments are being reformed, the rules of work in the field are changing, and adjustments are made to the usual process of activity.

2. Innovative contradictions that arise as a violation of the border between traditional production processes and innovative and bring changes in the work of the entire system.

3. Resistance on the part of personnel to innovative changes, which can have various forms of manifestation from passive disagreement to active resistance.

4. Lack of understanding by managers of different levels of management of the importance and benefits of innovation.

In the case of overcoming the above problems, the process of managing innovative-active enterprises should be focused on the following work:

- regulatory support, which provides for the legal protection of innovative products/services (patenting, certification, licensing);

- information support - consists in analyzing information about the market, competitors, consumer sentiment, society's reaction to innovative products;

- production and technical support - providing innovative processes with the necessary resources. To ensure maximum efficiency of the management process of an innovatively active enterprise, it is necessary:

- determine the most risky areas of the enterprise;

- use all available sources of innovative ideas; 
- to determine the quantitative indicators that need to be got in order to achieve the goals defined by the ongoing innovative projects;

- to determine the primary stages of work on implementing an innovative project, it is important to carry out the transition to the next stage only if the previous stage is fully completed.

Schematically, the structure of the management process of an innovative-active pidpryadstvo can be represented using Figure 8. Particular attention in the process of managing an innovatively active enterprise deserves the implementation of actions to ensure economic security, because it is this activity that allows the risks and threats posed by the operating environment to be taken into account as much as possible, as well as to adapt to changes, to avoid or minimize the consequences of their impact on the enterprise or its innovative projects.

When implementing the management of an innovatively active enterprise, it is necessary to understand that only a thorough study of the influence of the internal and external environment with their inherent risks, threats or opportunities, as well as the use of the entire set of security methods, will allow achieving the desired results and the set goals of the activity.

The COVID-19 coronavirus pandemic has made a significant impact on all business and management in the world. The worldwide suspension of businesses that have never stopped operations has made adjustments to how they are managed. The top management of world companies faced the question of how to keep the company at the achieved level, to continue the projects started and not to lose qualified employees. A significant negative impact on the world economy from the COVID-19 pandemic was estimated at the UN at US \$ 3.4 billion (Lozovsky \& Glukhova, 2020). Large companies manage to exit with fewer losses, but small and medium-sized businesses are very difficult. Managers are in a difficult situation and do not know what to do to keep companies afloat. Therefore, safety issues in the management process come to the fore and require significant analysis.

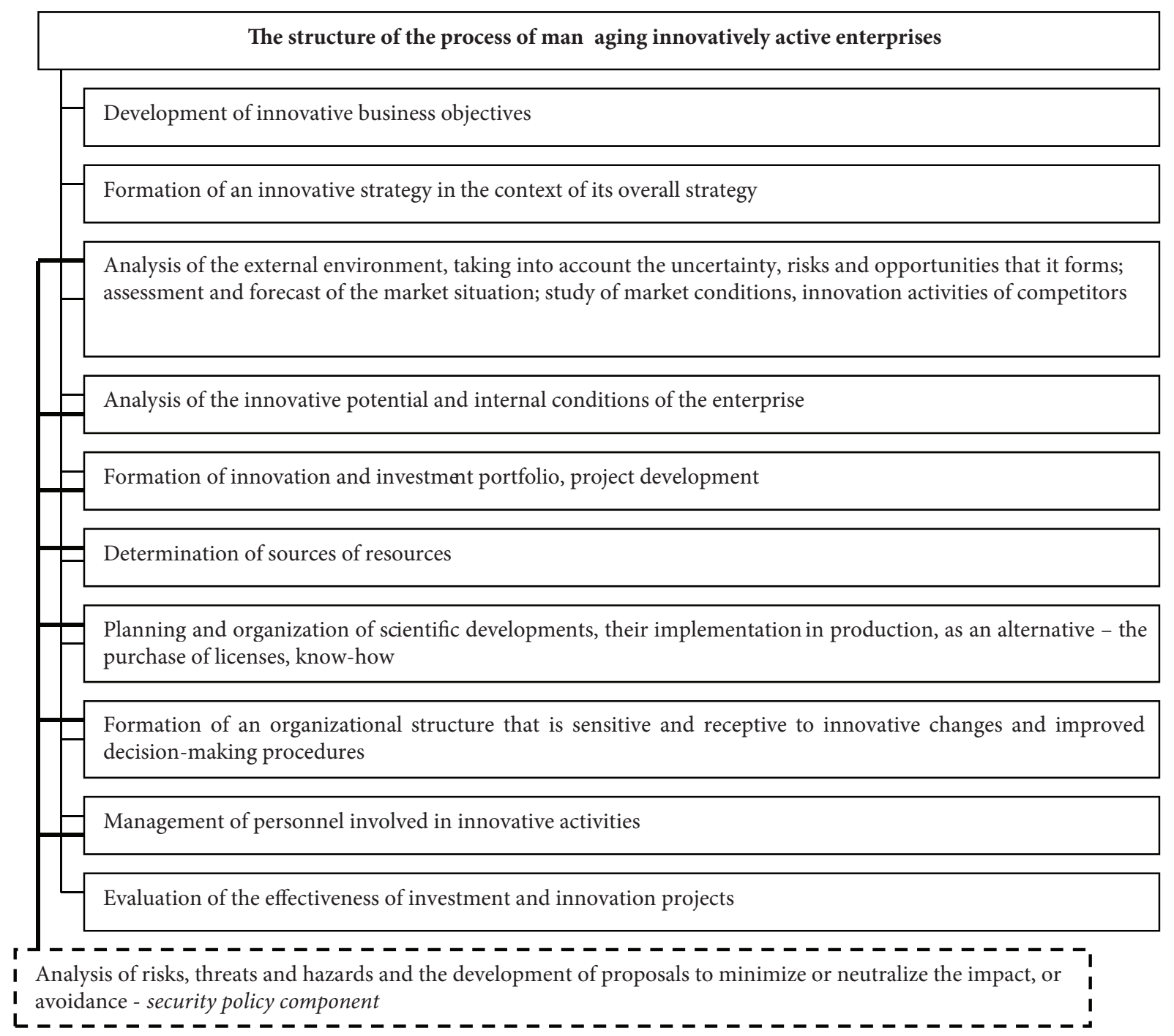

Figure 8 . The structure of the management process of innovative enterprises, considering aspects of security activities 


\section{Conclusions}

Thus, the features of understanding the innovative activity of enterprises have been investigated. The output and resulting categories in this area have been determined. The parameters of innovative activity of modern enterprises are analyzed. The emphasis is made on the fact that in the process of managing the innovative activity of enterprises; it is necessary to pay significant attention to the development of the innovative potential of employees and the formation of a favorable corporate culture, because only for comfortable conditions, employees can willingly work to achieve maximum results. The results of the study of innovations as a factor in strengthening the economic security of an enterprise in the context of globalization and integration into the world economic space give grounds for the conclusion that at the present stage of reformatting the current domestic economic system and the search for new methods, forms and methods of carrying out production, technological and technical activities is an urgent need and a global challenge. The problem of increasing the innovative factor, which is an integral component of scientific and technological progress in the system of economic ties based on competitiveness and the activation of innovative development, turns into a priority area for strengthening the economic security of an enterprise, the level of which depends on global indices.

The prospect of further research determined the formation of the optimal organizational structure of innovatively active enterprises, which will cover all links of the management process, and will also contribute to the implementation of measures to ensure economic security.

\section{Author contributions}

The authors contributed equally.

\section{Disclosure statement}

The authors do not have any conflict of interest.

\section{References}

Abebe, A., Daniels, J., McKean, J. W., \& Kapenga, J. A. (2000). Statistics and data analysis. Statistical Computation Lab, Western Michigan University.

http://mis.kp.ac.rw/admin/admin_panel/kp_lms/files/digital/ CoreBooks/Core\%20Books\%20in\%20Education/E304_\%20 $\% 20$ Intiation $\% 20$ to $\% 20$ Statistics $\% 20 \% 20$ Statistics $\% 20$ and\%20Data\%20Analysis.pdf

Boronos, V. G., \& Shkarupa, O. V. (2020). Strategic orientation of innovative activity regulation: Ukraine and EU integration process. Financial and Credit Activity: Problems of Theory and Practice, 1(32), 307-318.

https://doi.org/10.18371/fcaptp.v1i32.200526

Dachs, B., Ebersberger, B., \& Lööf, H. (2008). The innovative performance of foreign-owned enterprises in small open economies. The Journal of Technology Transfer, 33(4), 393406. https://doi.org/10.1007/s10961-007-9058-7
Duhan, P., \& Singh, A. (2014). Enterprise 2.0: a boon or bane for entrepreneurial and innovative expenditures? Journal of Innovation and Entrepreneurship, 3(1), 15. https://doi.org/10.1186/s13731-014-0015-Z

Global Innovation Index. (2019). Creating healthy lives - the future of medical innovation. https://www.globalinnovationindex. org/userfiles/file/reportpdf/gii-full-report-2019.pdf

Grizovska, L. A. (2014). Factors of motivation in increasing the efficiency of innovative activities of an enterprise. Khmelnytsky National University Bulletin, 2, 90-94.

Guk, A. V., \& Korobeynik, A. V. (2010). Staffing for innovative activities of domestic and foreign enterprises.

https://scholar.google.com.ua/scholar?hl=ru\&as_sdt=0,5\&clu ster $=11186080534834846447$

Gurieva, L. K., Akhmetshin, E. M., Savicheva, A. N., Kataeva, V. I., \& Norkina, A. N. (2016). Theoretical foundations of management of the organization: development, types of structures, management methods of control. International Business Management, 10(22), 5406-5416.

Iastremska, O. M., \& Stokovych, H. (2019). Main trends of investment and innovative activity of business entities in the conditions of European integration. Innovative Tachnologies and Scientific Solutions for Industries, 1(7), 130-141. https://doi.org/10.30837/2522-9818.2019.7.130

Iastremska, O., Strokovych, H., Dzenis, O., Shestakova, O., \& Uman, T. (2019). Investment and innovative development of industrial enterprises as the basis for the technological singularity. Problems and Perspectives in Management, 17(3), 477-491. https://doi.org/10.21511/ppm.17(3).2019.38

Ivanchenko, V. (2010). Features of the use of non-material incentives at domestic enterprises. Economist, 3, 21-23.

Lazonick, W. (2011). Innovative enterprise and economic development. In W. Naudé (Ed.), Entrepreneurship and economic development (pp. 18-33). Palgrave Macmillan.

https://doi.org/10.1057/9780230295155_2

Lewandowska, M., Szymura-Tyc, M., \& Gołebiowski, T. (2016). Innovation complementarity, cooperation partners, and new product export: Evidence from Poland. Journal of Bisness Reaserch, 69, 3673-3681.

https://doi.org/10.1016/j.jbusres.2016.03.028

Lombardi, P., Giordano, S., Caragliu, A., Del Bo, C., Deakin, M., Nijkamp, P., Kourtit, K., \& Farouh, H. (2012). An advanced triple-helix network model for smart cities performance. In Regional development: concepts, methodologies, tools, and applications. IGI Global. https://doi.org/10.4018/978-1-4666-0882-5.ch808

Lozovsky, A. N., \& Glukhova, N. V. (2020). Features of innovation strategies as a driving factor for the development of innovation in enterprises. https://mivt.nmu.org.ua/ua/gluhova.php

Nursoy, M., Bazhirov, K. N., Markhaeva, B. A., \& Bazhirov, T. S. (2012). An innovative project management model for technological development of an enterprise. Theoretical Foundations of Chemical Engineering, 46(6), 618-620. https://doi.org/10.1134/S0040579512050156

Olefirenko, O., \& Shevliuga, O. (2017). Commercialization of innovations: peculiarities of sales policy at innovation active enterprise. Innovative Marketing, 13(2), 6-12. https://doi.org/10.21511/im.13(2).2017.01

Ranft, A. L., \& Lord, M. D. (2002). Acquiring new technologies and capabilites: a grounded model of acquisition implementation. Organization Science, 13(4), 420-441. https://doi.org/10.1287/orsc.13.4.420.2952 
Seifert, M., Thoben, K. D., \& Sitek, P. (2007). Consortium building in enterprise networks to design innovative products. In J. Olhager \& F. Persson (Eds.), Advances in Production Management Systems: International IFIP TC 5, WG 5.7 Conference on Advances in Production Management Systems (APMS 2007) (pp. 121-131). Springer. https://doi.org/10.1007/978-0-387-74157-4_15

Sharp, B. M., Iyer, D. N., \& Brush, T. H. (2017). Executive influence on invention and commercialization: The moderating role of innovation radicalness. American Journal of Business, 32(3-4), 134-151. https://doi.org/10.1108/AJB-11-2016-0036

Shpak, N., Kniaz, S., Myroshchenko, N., \& Kolomiyets, O. (2014). Commercialization of high-tech products: theoretical-methodological aspects. Econtechmod, 3(1), 81-88.

Wyrwa, J. (2020). A review of the European Union financial instruments supporting the innovative activity of enterprises in the context of Industry 4.0 in the years 2021-2027. Entrepreneurship and Sustainability Issues, 8(1), 1146-1161. https://doi.org/10.9770/jesi.2020.8.1(77) 